\title{
Criminalisation of transmission of SARS-CoV-2: A potential challenge to controlling the outbreak in South Africa
}

\author{
S Abdool Karim, LLB, LLM (Global Health Law), PhD (Law) candidate (University of KwaZulu-Natal) \\ PRICELESS SA, School of Public Health, Faculty of Health Sciences, University of the Witwatersrand, Johannesburg, South Africa; \\ SAMRC/WITS Centre for Health Economics and Decision Science Research Unit, Johannesburg, South Africa
}

Corresponding author: S Abdool Karim (safura.abdoolkarim@wits.ac.za)

\begin{abstract}
In March 2020, two cases of attempted murder were opened against people who had tested positive for COVID-19 and had not remained in quarantine. Criminal law has previously been used to criminalise intentional transmission of HIV in both South Africa (SA) and other countries. However, it has been found that criminalisation laws undermine public health and measures to control outbreaks by stigmatising those infected and deterring testing. This article explores whether SA's existing HIV criminalisation laws can be applied to the transmission of SARS-CoV-2, and the potential effect such measures could have on efforts to control the COVID-19 epidemic.
\end{abstract}

S Afr Med J 2020;110(6):458-460. https://doi.org/10.7196/SAMJ.2020.v110i6.14753

As of 26 March 2020, two people had been arrested and charged with attempted murder after they tested positive for SARS-CoV-2 and did not self-quarantine. ${ }^{[1]}$ One of the suspects, a salon owner in Ladysmith, had tested positive after travelling. Despite being instructed to enter quarantine, he instead continued to work and even attended a religious gathering. ${ }^{[2]}$ Before he was arrested, the salon owner exposed at least 27 people to SARS-CoV-2, and he was charged with attempting to murder them. ${ }^{[2]}$ It will be some time before there is a decision in these cases on whether exposing others to the coronavirus constitutes attempted murder. However, now that the door has been opened to the use of criminal law to address noncompliance with the regulations, it is worth considering how these cases differ from previous contraventions of the regulations and what the implications of a conviction could be on efforts to contain the outbreak.

These cases are the first criminal cases related to the COVID19 outbreak, and at present they are based solely on the accused exposing people to the virus. It is debatable whether mere exposure to a virus is currently criminalised under South African (SA) law, as some have argued that the $S v$ Phiri case has criminalised exposure to HIV ${ }^{[3,4]}$ However, if those who were exposed to the virus become infected, the conduct of the accused may amount to a crime, because intentionally infecting someone with a virus currently constitutes a crime under SA law.

In 2005, SA became one of 68 countries that criminalise HIV transmission, when the intentional transmission of HIV was found to constitute attempted murder. ${ }^{[5,6]}$ A number of countries criminalised HIV transmission through the introduction of HIV-specific laws. The scope of these laws varies significantly. For example, the Zimbabwean criminal code criminalises both transmission and conduct that involves a 'real risk' of transmission. ${ }^{[7]}$ In contrast, many of the statelevel laws adopted in the USA criminalise exposure unless an HIVpositive individual discloses their status to their partner, while other states criminalise low-risk conduct such as biting and spitting. ${ }^{[8]} \mathrm{SA}$ courts opted to follow an approach similar to the finding by Canadian courts that infecting someone with HIV would constitute assault, but used the crime of attempted murder. This means that the offences are not limited to transmission of HIV.

Owing to the nature of criminal law, the principles that apply to HIV transmission could be applicable to transmission of SARSCoV-2. However, there is also room to reconsider the role criminal law should have in the context of epidemic control and public health more broadly. Since the cases cited above were decided, there has been a growing body of research and increased scientific consensus that criminalising HIV transmission undermines public health efforts. ${ }^{[6,9,10]}$ At a crossroads in the COVID-19 outbreak, we should consider the potential impact these cases may have on ongoing public health efforts.

\section{Criminal offences related to the spread of COVID-19 in SA}

The current legal framework in SA has two mechanisms to attach criminal liability to the transmission of SARS-CoV-2.

The first is under the regulations adopted after the COVID-19 outbreak was declared a national State of Disaster (the Disaster Management Regulations). ${ }^{[11]}$ Under the Disaster Management Regulations, people who have been diagnosed as having COVID-19 or are suspected of having contracted or being in contact with a carrier of COVID-19 can be compelled to be in quarantine or self-isolation, or admitted to a hospital if instructed to do so (regulation 4). ${ }^{[11]}$ In addition, such persons must undergo the necessary 'mandatory prophylaxis, treatment, isolation or quarantine or isolation in order to prevent transmission. ${ }^{\text {'[1] }}$ There have been a number of cases brought for contraventions of these regulations, specifically against individuals who have refused to be quarantined. ${ }^{[12]}$ These offences are specific to the COVID-19 outbreak and only apply during the State of Disaster. ${ }^{[13]}$ Convictions arising from a contravention of the regulations can result in a fine and/or up to 6 months of prison time (regulation 11). ${ }^{[11]}$

The second mechanism, which will be outlined in more detail below, involves using existing laws criminalising attempted murder to criminalise transmission of SARS-CoV-2. This penal mechanism 
is a stark contrast to the milder, effectively administrative offences described above. Since charges of attempted murder use existing criminal laws, cases could continue to be brought for the transmission of the coronavirus well after the State of Disaster ends. In addition, although there are no minimum sentences set for attempted murder, sentences are often lengthy and exceed the maximum penalties set by the Disaster Management Regulations. ${ }^{[14]}$ As a result, extending the criminalisation of transmission of the coronavirus to include attempted murder is far more serious than existing offences under the Disaster Management Regulations.

\section{Criminalisation of HIV transmission using attempted murder laws}

Fifteen years ago, the Transvaal High Court (now the Pretoria High Court) convicted Mr Nyalangu for attempted murder after it was found that he had intentionally infected a woman with HIV. The basis of the conviction was Mr Nyalangu's knowledge of his HIV-positive status at the time he raped the complainant. This case cemented intentional transmission of HIV as a crime in SA. At the time, access to antiretroviral (ARV) drugs was very limited in the public sector, ${ }^{[15]}$ so HIV mortality was high. ${ }^{[16]}$ Owing to the impact of HIV on life expectancy, intentionally infecting someone would constitute attempted murder. ${ }^{[5]}$

The next HIV transmission case came many years later when the landscape of ARV access had changed dramatically. ${ }^{[16]}$ In 2013, Mr Mphikelili Phiri was convicted for attempted murder after he infected his girlfriend with HIV. ${ }^{[4]}$ The circumstances were slightly different to the previous case, as Mr Phiri knew he was HIV-positive, but the sex was consensual. However, Mr Phiri had claimed to be HIV-negative and refused to wear a condom when asked to do so. ${ }^{[4]}$ Despite the changes in life expectancy of HIV-positive persons on ARV treatment, the High Court once more found that because HIV diminished or shortened a person's lifespan, intentionally infecting someone could constitute attempted murder. ${ }^{[4]}$

Of critical importance is that in both of these cases, conviction was only possible because the accused knew his status. This requirement is linked to a broader concern that criminalisation of HIV transmission will deter people from being tested, and the resulting fall in uptake of testing could lead to increased rates of infection, undermining efforts to curb the spread of the disease. ${ }^{[9,10,17-19]}$ The importance of testing is even greater for a highly infectious disease such as COVID-19, and scaling up testing has been a lynchpin in efforts to control the outbreak. $^{[20]}$

\section{Applicability of HIV criminalisation to COVIID-19 cases}

Before we consider the potential public health impact of criminalising transmission of SARS-CoV-2, it is necessary to establish how the principles of the previous HIV cases would apply to a case of spreading the coronavirus.

Based on the precedents set in previous cases, virus transmission attempted murder cases have unique requirements that need to be proved before someone may be convicted. These requirements include the following:

- The accused must have a communicable disease, be aware that they are infected, and have infected another person or people

- The accused must engage in behaviour that puts people at risk of being infected and accept that their actions put others at risk of contracting the virus

- The virus or disease must potentially diminish or shorten a person's lifespan.

\section{Knowledge that one has a communicable disease}

For the first requirement to be fulfilled, the case must involve a communicable disease. Both HIV and COVID-19 are communicable diseases that can be spread from person to person. As a result, it is possible to criminalise the spread of SARS-CoV-2, as was done with HIV. The issue of importance is what would constitute knowledge or awareness that one is infected. In HIV cases, a diagnosis confirmed through a laboratory test was required, but it is unclear in the case of COVID-19 whether knowledge and presence of symptoms would be considered sufficient to meet this requirement. In the cases currently pending, both individuals knew that they had contracted the virus and that they were required to quarantine themselves to avoid spreading it, so this criterion is met. What is currently unknown about these pending cases is whether those exposed to the virus contracted it. The highly infectious nature of SARS-CoV-2 could lead to a finding by courts that exposure to the virus constitutes a significant enough risk to constitute attempted murder, but this would be a radical departure from existing case law.

Engage in behaviour that puts others at risk of infection This requirement is linked to the intention of the infected individual in exposing others to the virus. Previous cases have clarified that for cases involving the transmission of HIV, this element does not require an intention to kill, but can be met if an individual foresees that a person may be infected as a result of their conduct and reconciles themselves to this risk. ${ }^{[3]}$

This requirement may evolve substantially as knowledge of transmission of a disease, as well as preventive measures such as vaccines, and treatments for it, become increasingly more available and sophisticated. However, criminal law is often not sufficiently flexible to accommodate such developments in healthcare. ${ }^{[17]}$ What constitutes behaviour that spreads a disease will differ depending on the disease. Although all the ways SARS-CoV-2 is spread are not known, it is currently thought to spread primarily through droplets released when an infected person sneezes or coughs. ${ }^{[21]}$ Consequently, behaviour that risks infecting others would consist of any interaction an infected person has with other people where virus-carrying droplets may come into contact with them.

An important example of how the criminal law may adjust to accommodate innovations in treatment is found in the Canadian case of $R v$ Maboir. ${ }^{[22]}$ From 1998, the Canadian case $R v$ Cuerrier ${ }^{[23]}$ had criminalised intentional HIV transmission, and this had formed the basis for SA's cases. However, Maboir changed this, recognising that a person could not be convicted for exposing someone to HIV if they were virally suppressed and therefore at low risk of infecting another. ${ }^{[22]}$ SA cases have not yet considered whether taking steps to reduce the risk of transmission of SARS-CoV-2, such as wearing a mask to reduce spread, would provide a defence to these charges. However, without accommodation for preventive measures, laws criminalising virus transmission risk discriminating against those who are infected and further stigmatising them. ${ }^{[6]}$

\section{The virus negatively affects lifespan}

This requirement is more complicated to apply to SARS-CoV-2 than HIV, because although COVID-19 can have a severe impact on the health of older people or those with underlying illnesses, ${ }^{[24]}$ its health impact on younger, healthy populations is generally quite mild. ${ }^{[24]}$ In addition, the long-term effects of the coronavirus, even in mild cases, are unknown because the virus is still so new.

In the HIV transmission cases, the courts took a broad approach to defining how negative a health outcome was necessary to justify a 
conviction. In Phiri, it was decided that because HIV could shorten a person's lifespan, transmitting it could be classed as attempted murder despite the fact that treatment is effective and available. ${ }^{[4]}$ The question of whether someone can be convicted of attempted murder for spreading SARS-CoV-2 is open, but could be guided by previous cases on HIV.

Although it will be up to the courts, it is possible that the severity of infecting others with SARS-CoV-2 could be treated in the same way HIV was treated 15 years ago.

\section{Potential impact on public health efforts}

Should there be convictions for the transmission of SARS-CoV-2, SA will become one of the first countries to criminalise transmission. Although it is possible to view intentional transmission as attempted murder under existing SA laws, there is a chance that this will have a negative impact on public health efforts to control the outbreak. HIV criminalisation laws have been heavily criticised for leading to stigma. ${ }^{[3,9,10,17,18]}$ In addition, research done in Scotland indicated that criminalisation would reduce the uptake of HIV testing. ${ }^{[19]}$ Research in the USA found that HIV criminalisation was not an effective intervention to promote safer behaviours. ${ }^{[9,25]}$ In many ways, the stigma and other negative effects of HIV criminalisation have undermined public health responses. ${ }^{[3,10]}$

The same concerns arise regarding public health responses to COVID-19, which are relying on scaling up testing and quarantine of those infected to prevent further spread of the virus. The World Health Organization (WHO)'s guidance on reducing stigma related to COVID-19 recognises the links between criminalisation and stigma, and the negative impact they have on public health. In this regard, the WHO explicitly discourages ' $[\mathrm{u}]$ sing criminalising or dehumanising terminology [which] creates the impression that those with the disease have somehow done something wrong or are less human than the rest of us, feeding stigma, undermining empathy, and potentially fuelling wider reluctance to seek treatment or attend screening, testing and quarantine. ${ }^{[26]}$

In addition, criminalisation of the transmission of SARS-CoV-2 is likely to disproportionately target the poorest and most vulnerable South Africans. While wealthier South Africans have private homes with amenities such as clean running water and an excess of private space, those who are poorer are likely to live in small informal shelters that are overcrowded and have limited space and a lack of water ${ }^{[27-29]}$ In this context, quarantine, self-isolation and even taking measures such as handwashing to prevent the spread of the disease are all difficult if not impossible. Someone who is diagnosed with COVID-19 and has no choice but to stay in a small informal settlement with many other people could find themselves subject to the same punishment as the two men who chose to disregard quarantine instructions and face attempted murder charges.

\section{Conclusions}

Although SA finds itself in the territory of deciding whether to criminalise transmission of SARS-CoV-2, it is with the benefit of hindsight. Using lessons learnt from the failings of HIV criminalisation laws, there is an opportunity to avoid the same mistakes for the coronavirus and ensure that public health is prioritised. We should not employ the criminal law in a manner that will undermine efforts to promote testing and control the spread of the virus.

\section{Declaration. None.}

Acknowledgements. I thank Prof. Karen Hofman and Prof. Salim S Abdool Karim for their comments and insights on this article.

Author contributions. Sole author.

Funding. The research reported in this publication was partly supported by the South African Medical Research Council.

Conflicts of interest. None.

1. Daily Mail Online. Two people face attempted murder charges for defying quarantine in South Africa. https://www.dailymail.co.uk/news/article-8155511/Two-people-face-attempted-murder-chargesdefying-quarantine-South-Africa.html (accessed 28 March 2020).

2. RTE. Two South Africans charged with attempted murder for failing to self-isolate. 25 March 2020 https://www.rte.ie/news/coronavirus/2020/0325/1126384-attempted-murder-charges-for-failing-
her https://www.rte.ie/news/coronavirus/2020/03

3. Nienaber A. The 'intentional' sexual transmission of HIV: A note of caution in light of Phiri $v$ S: Case note. South Afr Public Law 2014;29(2):522-333. http://hdl.handle.net/2263/45445 (accessed 21 April 2020).

4. South Africa. Phiri v S 2013 ZAGPPHC 279. 2013.

5. South Africa. S v Nyalungu 2005 JOL 13254 (T).

6. Barré-Sinoussi F, Abdool Karim SS, Albert J, et al. Expert consensus statement on the science of HIV in the context of criminal law. J Int AIDS Soc 2018;21(7):e25161. https://doi.org/10.1002/jia2.25161 Zimbabwe. Criminal Law (Codification and Reform) Act 23 of 2004, Chapter 9 .

8. Lehman JS, Carr MH, Nichol AJ, et al. Prevalence and public health implications of state laws that criminalize potential HIV exposure in the United States. AIDS Behav 2014;18(6):997-1006. https:// doi.org/10.1007/s10461-014-0724-0

9. O'Byrne P, Bryan A, Roy M. HIV criminal prosecutions and public health: An examination of the empirical research. Med Humanit 2013;39(2):85-90. https://doi.org/10.1136/medhum-2013-010366

10. Hall HI, Holtgrave DR, Maulsby C. HIV transmission rates from persons living with HIV who Hall HI, Holtgrave DR, Maulsby C. HIV transmission rates from persons living with HIV who
are aware and unaware of their infection. AIDS 2012;26(7):893-896. https://doi.org/10.1097/ are aware and unaware
QAD.0b013e328351f73f

11. South Africa. Disaster Management Act of 2002. Regulations issued in terms of section 27(2) of the Disaster Management Act, 2002. Government Gazette No. 43107:318. 18 March 2020. https://www. saps.gov.za/newsroom/convid_regulations_2020.pdf (accessed 28 March 2020).

12. Makhetha T. Covid-19 family ran and lied about father's whereabouts. Sowetan Live, 19 March 2020 https://www.sowetanlive.co.za/news/south-africa/2020-03-19-covid-19-family-ran-and-lied-aboutfathers-whereabouts/ (accessed 28 March 2020).

13. Disaster Management Act, 2002 (Act No. 57 of 2002). Government Gazette No. 2444252:98 15 January 2003. http://www.cogta.gov.za/cgta_2016/wp-content/uploads/2016/06/DISASTERMANAGEMENT-ACT.pdf (accessed 28 March 2020).

14. Sloth-Nielsen J, Ehlers L. Assessing the impact: Mandatory and minimum sentences in South Africa. S Afr Crime Q 2005;14. https://journals.assaf.org.za/index.php/sacq/article/view/1005 (accessed 28 March 2020)

15. Johnson LF. Access to antiretroviral treatment in South Africa, 2004 - 2011. South Afr J HIV Med 2012;13(1):22-27. https://doi.org/10.4102/saihivmed.v13i1.156

16. Johnson LF, May MT, Dorrington RE, et al. Estimating the impact of antiretroviral treatment on adult mortality trends in South Africa: A mathematical modelling study. PLoS Med 2017;14(12):e1002468. https://doi.org/10.1371/journal.pmed.1002468

17. Burris S, Cameron E. The case against criminalization of HIV transmission. JAMA 2008;300(5):578581. https://doi.org/10.1001/jama.300.5.578

18. Mykhalovskiy E. The problem of 'significant risk': Exploring the public health impact of criminalizing HIV non-disclosure. Soc Sci Med 2011;73(5):668-675. https://doi.org/10.1016/j. socscimed.2011.06.051

19. Bird SM, Brown AJL. Criminalisation of HIV transmission: Implications for public health in Scotland. BMJ 2001;323(7322):1174-1177. https://doi.org/10.1136/bmj.323.7322.1174

20. World Health Organization. Responding to community spread of COVID-19: Interim guidance. 7 March 2020. Report No.: WHO/COVID-19/Community_Transmission/2020.1. https://www.who. int/publications-detail/responding-to-community-spread-of-covid-19 (accessed 28 March 2020).

21. Centers for Disease Control and Prevention. Coronavirus Disease 2019 (COVID-19): Transmission. https://www.cdc.gov/coronavirus/2019-ncov/prepare/transmission.html (accessed 28 March 2020). https://www.cdc.gov/coronavirus/2019-n
Canada. R. v. Mabior [2012] 2 SCR 584.

22. Canada. R. v. Mabior [2012] 2 SCR 584.

23. Canada. R. v. Cuerrier [1998] 2 SCR 3714/.
24. World Health Organization. Q\&A on coronaviruses (COVID-19). 8 April 2020, https://www.who.int/ World Health Organization. Q\&A on coronaviruses (COVID-19). 8 Apt
news-room/q-a-detail/q-a-coronaviruses (accessed 28 March 2020).

25. Burris S, Beletsky L, Burleson JA, Case P, Lazzarini Z. Do criminal laws influence HIV risk behavior? An empirical trial. Arizona State Law Journal 2007; Temple University Legal Studies Research Paper No. 2007-03. https://papers.ssrn.com/abstract=977274 (accessed 15 April 2020).

26. World Health Organization. A guide to preventing and addressing social stigma. Updated 24 February 2020. https://www.who.int/docs/default-source/coronaviruse/covid19-stigma-guide. pdf (accessed 28 March 2020).

27. Abdool Karim A. No water, no room: Containing an outbreak in South Africa. Bhekisisa Centre for Health Journalism, 18 March 2020. https://bhekisisa.org/health-news-south-africa/2020-03-18-nowater-no-room-containing-an-outbreak-in-south-africa/ (accessed 28 March 2020).

28. Lali BV. Covid-19: It's hard to wash your hands when 380 families share three taps. GroundUp News, 25 March 2020. https://www.groundup.org.za/article/covid-19-its-hard-wash-your-handsNews, 25 March 2020. https://www.groundup.org.za/article/co
when-380-families-share-three-taps/ (accessed 28 March 2020).

29. Harvey H. COVID-19 pandemic: In a nation of extreme inequality, South Africass poorest are most at risk. Atlantic Council, 24 March 2020. https://www.atlanticcouncil.org/blogs/africasource/covid19-pandemic-in-a-nation-of-extreme-inequality-south-africas-poorest-are-most-at-risk/ (accessed 28 March 2020).

Accepted 20 April 2020. 